\title{
Inclusive Education through the Implementation of Creative Industry Learning Model for Disabilities
}

\author{
Sahabuddin Sidiq \\ Faculty of Economics \\ Islamic University of Indonesia \\ Heri Sudarsono \\ Faculty of Economics \\ Islamic University of Indonesia \\ Sarastri Mumpuni Ruchba \\ Faculty of Economics \\ Islamic University of Indonesia \\ Andika Ridha Ayu Perdana \\ Faculty of Economics \\ Islamic University of Indonesia
}

This research is sponsored by Ministry of Research, Technology and Higher Education of the Republic of Indonesia and supported by CIQAL (Center for Improving Qualified Activity in Life of People with Disabilities)

\begin{abstract}
Inclusive education accommodates the educational needs of students by using various instructional methods. This article aims to find out the effectiveness of implementing creative industry learning models for people with disabilities. The learning model tested is based on physical and mental limitations of the people with deafness, blindness, physically disabled, and mentally disabled. There are four clasess of the specific learning in the model which are cooking, crafts, computer technique, and music. The result shows that people with disabilities generally can follow the learning process in accordance with the learning model. However, each class has different types of difficulties depending on the types of disabilities. Other result shows that the learning process for people with mental disabilities is more difficult than other types of disabilities. In addition, the presence of assistant for escorting student in the learning process is essential.
\end{abstract}

Keyword: inclusive education, learning model, learning process, people with disabilities

\section{Introduction}

Inclusive education accommodates the diversity of educational needs of students by using various instructional methods. It is not only done through the integration, but also provides curriculum and support services for the needs of people with disabilities. The implementation of inclusive education right now does not remarkably consider the potential condition of people with disabilities. (Sidiq et al, 2018). In the context of education, the inclusion approach in its practice provides them with more opportunities to understand, realize themselves, and develop their potential with whole freedom and creativity in the atmosphere of ordinary education. (Sulthon, 2013). The inclusive concept tries to show that every student with disability has more similarities compared to the differences. In this case, all students must be welcomed friendly by members of their learning community, since all individuals basically have these rights within communities. (Andayani \& Afandi, 2016). the concept of inclusive education is also regulated in law, so that in practice it has a strong foundation. (Friend \& Bursuck, 2015)

An inclusive practice represents a philosophy that is based on three dimensions: 1) Physical Integration: placing students in the same room as non-disabled students must be a top priority. Pulling them out in this realm should only be done if necessary. Inclusiveness does not mean that all students must always be in the realm of general education. 2) Social Integration: relationships between students with disabilities with classmates, peers, and adults must still be maintained. Possible areas to achieve this goal are the realm of general education, without ruling out the possibility for students with disabilities to interact with the peers in special education classes. 3) Teaching Integration: most students are taught the same curriculum that is used for non-disabled students by adjusting the design of teaching and learning. (Griffin \& Nechvoglod, 2008; Efendi \& Yunianto, 2017), 
In the context of special education in Indonesia, inclusive education is not the only way to educate disabled children with a view to replacing segregation of education that was previously used as an educational concept for them. However, this is an alternative, choice, innovation, or breakthrough/new approach besides segregation of education which has been running for more than a century. This is due to the special education or special education settings in Indonesia adopting the Roach Multi- Track App approach. (Ilahi. 2016)

Formally, inclusive education in Indonesia has only been implemented in the past decade. However, it is believed that naturally inclusive education has been going on for a long time. It is not separated from the factors of filosofi, social, and cultural of Indonesia which have highly appreciates and upholds the diversity. (Amalia, 2014)

This article examines the learning model of creative industries for people with disabilities fostered by the NonGovernment Organization called CIQAL (Center for Improving Qualified Activity in Life of People with Disabilities). The creative teaching model of this creative industry is based on the limitations of the types of people with disabilities, which consist of deaf, blind, physically disabled and mentally disabled. The purpose of this study is to see the effectiveness of the implementation of classical teaching models based on the types of the disabilities.

\section{Research Methods}

This research uses descriptive analysis method which aims to explain the results of the implementation of the learning model of creative industry for people with disabilities. Table 1 shows the learning curriculum model used to help a teacher to be able to meet learning targets. Structures, assistants, syllabi, modules, equipment and materials are provided for each type of training in the classroom since each training for every type of disabilities has a different difficulty factor.

Table 1. Curriculum Creative Industries Learning for Disability

\begin{tabular}{|c|c|c|c|c|c|c|}
\hline $\begin{array}{c}\text { Type of } \\
\text { disabilities }\end{array}$ & Type of activity & Module & assistant & Meeting & Props & Material \\
\hline \multirow[t]{4}{*}{ Deaf } & Culinary / Cooking & Available & $5 / 1$ & $\begin{array}{l}150 / \\
\text { topic }\end{array}$ & $\begin{array}{l}\text { Video / } \\
\text { photo }\end{array}$ & Stoves, pans, pans, \\
\hline & Design / Sewing & Available & $5 / 1$ & $\begin{array}{l}150 / \\
\text { topic }\end{array}$ & $\begin{array}{l}\text { Video / } \\
\text { photo }\end{array}$ & $\begin{array}{l}\text { Sewing machine, cloth, } \\
\text { needle }\end{array}$ \\
\hline & $\begin{array}{l}\text { Craft I } \\
\text { Handicraft an }\end{array}$ & Available & $5 / 1$ & $\begin{array}{l}150 / \\
\text { topic }\end{array}$ & $\begin{array}{l}\text { Video / } \\
\text { photo }\end{array}$ & Fabric, needle, \\
\hline & $\begin{array}{l}\text { Electronics / } \\
\text { Computers } \\
\end{array}$ & Available & $5 / 1$ & $\begin{array}{l}300 / \\
\text { topic }\end{array}$ & $\begin{array}{l}\text { Video / } \\
\text { photo }\end{array}$ & $\begin{array}{l}\text { Electricity, cable, } \\
\text { electronic devices }\end{array}$ \\
\hline \multirow[t]{4}{*}{ Blind } & Culinary / Cooking & Available & $2 / 1$ & $\begin{array}{l}200 / \\
\text { topic }\end{array}$ & Sound & Stoves, pans, pans, pans \\
\hline & Design / Sewing & Available & $2 / 1$ & $\begin{array}{l}200 / \\
\text { topic }\end{array}$ & Flares a & $\begin{array}{l}\text { Sewing machine, cloth, } \\
\text { needle }\end{array}$ \\
\hline & Craft / Craft & Available & $2 / 1$ & $\begin{array}{l}200 / \\
\text { topic }\end{array}$ & Sound & $\begin{array}{l}\text { Fabrics, threads, needles, } \\
\text { glue }\end{array}$ \\
\hline & $\begin{array}{l}\text { Electronics / } \\
\text { Computers } \\
\end{array}$ & Available & $2 / 1$ & $\begin{array}{l}400 / \\
\text { topic }\end{array}$ & Sound & $\begin{array}{l}\text { Electricity, cable, } \\
\text { electronic devices }\end{array}$ \\
\hline \multirow[t]{4}{*}{ Physical } & Culinary / Cooking & Available & $10 / 1$ & $\begin{array}{l}150 / \\
\text { topic }\end{array}$ & $\begin{array}{l}\text { Video / } \\
\text { photo }\end{array}$ & Stove, pan, pan, pans \\
\hline & Design / Sewing & Available & $10 / 1$ & $\begin{array}{l}150 / \\
\text { topic }\end{array}$ & $\begin{array}{l}\text { Video / } \\
\text { photo }\end{array}$ & $\begin{array}{l}\text { Sewing machine, cloth, } \\
\text { needle }\end{array}$ \\
\hline & Craft / Craft & Available & $10 / 1$ & $\begin{array}{l}150 / \\
\text { topic }\end{array}$ & $\begin{array}{l}\text { Video / } \\
\text { photo }\end{array}$ & Fabric, needle, \\
\hline & $\begin{array}{l}\text { Electronics / } \\
\text { Computers } \\
\end{array}$ & Available & $10 / 1$ & $\begin{array}{l}150 / \\
\text { topic }\end{array}$ & $\begin{array}{l}\text { Video / } \\
\text { photo }\end{array}$ & $\begin{array}{l}\text { Electricity, cable, } \\
\text { electronic devices }\end{array}$ \\
\hline \multirow[t]{3}{*}{$\begin{array}{l}\text { Physical } \\
\text { Disabled }\end{array}$} & Culinary / Cooking & - & - & - & - & - \\
\hline & Design / Sewing & - & - & - & - & - \\
\hline & Craft / Craft & Available & $1 / 1$ & $\begin{array}{l}450 / \\
\text { topic }\end{array}$ & $\begin{array}{l}\text { Video / } \\
\text { photo }\end{array}$ & $\begin{array}{l}\text { Fabrics, threads, needles, } \\
\text { glue }\end{array}$ \\
\hline
\end{tabular}




\begin{tabular}{|c|c|c|c|c|c|c|}
\hline & $\begin{array}{l}\text { Electronics / } \\
\text { Computers }\end{array}$ & - & - & - & - & - \\
\hline \multirow[t]{4}{*}{$\begin{array}{l}\text { Physical- } \\
\text { Mental } \\
\text { Disabled }\end{array}$} & Culinary / Cooking & - & - & - & - & - \\
\hline & Design / Sewing & - & - & - & - & - \\
\hline & Craft / Hand Craft & Available & $1 / 1$ & $\begin{array}{l}450 / \\
\text { topic }\end{array}$ & $\begin{array}{l}\text { Video / } \\
\text { photo }\end{array}$ & $\begin{array}{l}\text { Fabrics, threads, needles, } \\
\text { glue }\end{array}$ \\
\hline & $\begin{array}{l}\text { Electronics / } \\
\text { Computers }\end{array}$ & - & - & - & - & - \\
\hline
\end{tabular}

Source: FGD Results of the research team with CIQAL NGO participants, 2018

In practice, music activity replaces the design activity due to the demand from the participant. Accordingly, this article addresses four activities which are cooking, crafting, using computer and playing music. These activities are the most likely to be learned by the types of people with disabilities that has previously mentioned.

The classes of learning process are based on the types of people with disabilities and creative industries. One class is designed only for one type of disability in order to achieve the effectiveness of the learning process. Having four types of creative industries that will be taught and four types of disabilities, the number of classes needed is 12 classes. Each creative industry class is carried out at different times for each type of disabilities. The class division is as follows:

Table 2. Division of Learning Process Classes

\begin{tabular}{ccccc}
\hline & Cooking & Crafting & $\begin{array}{c}\text { Using } \\
\text { Computer }\end{array}$ & Playing Music \\
\hline Deaf & 1 & 2 & 3 & - \\
\hline Blind & 4 & 5 & - & 6 \\
\hline Physically disabled & 7 & 8 & 9 & 10 \\
\hline Mentally disabled & - & 11 & - & 12 \\
\hline
\end{tabular}

Source: Classes of creative industry, 2019

Music class for the deaf is eliminated since they have difficulty in identifying the type of sound. The computer class for the blind is eliminated as well since the introduction of computer tools requires an accuracy. Cooking and computer classes are not recommended for mentally disabled considering the potential risk for this type of disabilities.

\section{Discussion}

\section{Class situation}

Learning activities for the disabilities carried out for two days from 09.00 to 15.00. Participants were divided into groups to join cooking class, craft class, computer class and music class. Each class consists of five students, one instructor and one assistant, except for mentally disabled which need more than one assistant.

\section{a. Cooking Class}

The learning process in the cooking class is conducted by an instructor and accompanied by an assitant. The first process is introducing the cake to be made, followed by explaining the ingredients provided, as well as the equipment used. The instructor teaches the participants to follow the instructor in preparing the dough from the materials that are already available. The activity of preparing the dough takes approximately 1-1.5 hours interspersed by several questions and answers between the instructor and participants. The next process is steaming the dough for 15-20 minutes. The same process happens in the class of the blind and physical disabled groups.

\section{b. Crafting Class}

The learning process for the crafting class is led by the instructor and accompanied by an assistant. After explaining the craft to be made, the materials provided and the equipment used, the instructor teaches students to follow the instructor in packaging the craft products. The activity of preparing and packing materials takes approximately 1.5 hours. Packaging material consists of some processes such as how to sew, how to arrange materials, how to make patterns, and how to put and choose color. During the packaging process, number of questions are asked by students to the instructor. The next process is the assessment on the product results of each student. The crafting class is carried out for all four types of disabilities. 


\section{c. Computer Class}

Like the implementation in other classes, the learning process in the computer class is led by the instructor and accompanied by an assistant. The instructor explains the purpose of assembling the computer, the materials provided, and the equipment used. Then, the instructor also explains to students to follow the instructor in removing and installing the materials that are already available. Learning activities in the form of preparing, removing and assembling the material takes approximately 2 hours. In the process of installing and assembling, the instructor also explains the names and functions of each device in the computer. Active question and answer also occurs in this class. This learning process is only implemented in classes for the deaf and physical disabled.

\section{d. Music Class}

The learning process for music class is also led by an instructor and accompanied by an assistant. First, the instructor explains the purpose of learning singing for disabilities, the equipment provided, and the equipment used. Then the instructor introduces good singing methods, introduces the sound types, introduces the musical instruments or singing accompaniment, and so on. The learning activity takes approximately 2 hours with the target that the participants are being able to sing at least one song. The learning process is carried out for the group of blind, physical disabled, and mentally disabled.

\section{Response of Instructors, Assistants and Students}

During the learning process, instructors and assistants are very influential in directing students in class. Each learning process in a different class has a different way of understanding students. The roles of instructors and assistants in each class can be formulated as follows:

Table 3. Responses from Instructor, Assistants, and Students

\begin{tabular}{|c|c|c|c|c|}
\hline Class & Disabilities & Instructor & Assistant & Students \\
\hline \multirow[t]{4}{*}{ Cooking } & Deaf & $\begin{array}{l}\text { The instructor gives step by } \\
\text { step instructions with } \\
\text { standard sentences to be } \\
\text { easily understood by } \\
\text { the assistant }\end{array}$ & $\begin{array}{l}\text { The assistant translates } \\
\text { each instructor's } \\
\text { instructions to students }\end{array}$ & $\begin{array}{l}\text { Students can follow the } \\
\text { learning process well, } \\
\text { assisted by assistants }\end{array}$ \\
\hline & Blind & $\begin{array}{l}\text { The instructor gives } \\
\text { instructions in stages with } \\
\text { standard sentences } \\
\text { accompanied by physical } \\
\text { touch. The instructor } \\
\text { introduces equipment and } \\
\text { cooking ingredients with } \\
\text { physical contact such as } \\
\text { holding, stroking or patting }\end{array}$ & $\begin{array}{l}\text { The assistants are } \\
\text { involved in helping the } \\
\text { instructor physically to } \\
\text { know and to touch the } \\
\text { ingredients. The ratio } \\
\text { of assistants and } \\
\text { students is } 1: 2 \text {, or } 1 \\
\text { assistant helps } 2 \\
\text { students }\end{array}$ & $\begin{array}{l}\text { Students need extra } \\
\text { assistance to be able to } \\
\text { understand the instructions } \\
\text { of the instructor. The } \\
\text { involvement of assistants in } \\
\text { understanding students is } \\
\text { quite high }\end{array}$ \\
\hline & $\begin{array}{l}\text { Physical } \\
\text { Disabled }\end{array}$ & $\begin{array}{l}\text { Instructors gives } \\
\text { instructions in stages with } \\
\text { standard sentences to be } \\
\text { easily understood by } \\
\text { students }\end{array}$ & $\begin{array}{l}\text { Assistants help the } \\
\text { students to reach the } \\
\text { equipments }\end{array}$ & $\begin{array}{l}\text { Students can follow the } \\
\text { learning process and the } \\
\text { involvement of assistant is } \\
\text { quite minimal since the } \\
\text { students understand what } \\
\text { they must do }\end{array}$ \\
\hline & $\begin{array}{l}\text { Mentally } \\
\text { disabled }\end{array}$ & - & - & - \\
\hline \multirow[t]{2}{*}{ Crafting } & Deaf & $\begin{array}{l}\text { The instructor gives step by } \\
\text { step instructions with } \\
\text { standard sentences to be } \\
\text { easily understood by the } \\
\text { assistant }\end{array}$ & $\begin{array}{l}\text { The assistant translates } \\
\text { each instructor's } \\
\text { instructions to students }\end{array}$ & $\begin{array}{l}\text { Students can follow the } \\
\text { learning process well, } \\
\text { assisted by assistants }\end{array}$ \\
\hline & Blind & $\begin{array}{l}\text { The instructor gives } \\
\text { instructions in stages with } \\
\text { standard sentences } \\
\text { accompanied by physical } \\
\text { touch. The instructor }\end{array}$ & $\begin{array}{l}\text { The assistants are } \\
\text { involved in helping the } \\
\text { instructor giving } \\
\text { instruction to the } \\
\text { students. They help }\end{array}$ & $\begin{array}{l}\text { Students need extra } \\
\text { assistance to be able to } \\
\text { understand commands from } \\
\text { the instructor. The } \\
\text { involvement of assistants in }\end{array}$ \\
\hline
\end{tabular}




\begin{tabular}{|c|c|c|c|c|}
\hline & & $\begin{array}{l}\text { introduces the equipment of } \\
\text { crafts with physical contact } \\
\text { such as holding, stroking or } \\
\text { patting }\end{array}$ & $\begin{array}{l}\text { student to touch and } \\
\text { use the equipment } \\
\text { carefully. The ratio of } \\
\text { assistants and students } \\
\text { is } 1: 2 \text {, or } 1 \text { assistant } \\
\text { helps } 2 \text { students }\end{array}$ & $\begin{array}{l}\text { helping students is quite } \\
\text { high }\end{array}$ \\
\hline & $\begin{array}{l}\text { Physical } \\
\text { Disabled }\end{array}$ & $\begin{array}{l}\text { Instructors provide step-by- } \\
\text { step instructions with } \\
\text { standard sentences to be } \\
\text { easly understood by students }\end{array}$ & $\begin{array}{l}\text { Assistants help } \\
\text { instructors to reach the } \\
\text { craft equipment }\end{array}$ & $\begin{array}{l}\text { Students can follow the } \\
\text { learning process and the } \\
\text { involvement of assistants } \\
\text { is quite minimal }\end{array}$ \\
\hline & $\begin{array}{l}\text { Mentally } \\
\text { disabled }\end{array}$ & $\begin{array}{l}\text { The instructor gives } \\
\text { instructions in stages } \\
\text { with standard languange to } \\
\text { be easily understood by the } \\
\text { assistants and } \\
\text { students. Assistants are } \\
\text { assisted by the parents of } \\
\text { students to carry out the } \\
\text { instructor's instructions }\end{array}$ & $\begin{array}{l}\text { Assistants are involved } \\
\text { in helping the parents } \\
\text { and students to } \\
\text { understand and focus } \\
\text { on the instructions, to } \\
\text { reach the craft } \\
\text { equipments, as well as } \\
\text { to use the craft tools }\end{array}$ & $\begin{array}{l}\text { Students must be } \\
\text { accompanied by assistants, } \\
\text { even parents, to follow the } \\
\text { instructions since most of } \\
\text { them tend not to focus in } \\
\text { class }\end{array}$ \\
\hline \multirow[t]{4}{*}{ Computer } & Deaf & $\begin{array}{l}\text { The instructor gives step by } \\
\text { step instructions with } \\
\text { standard sentences to be } \\
\text { easily understood by the } \\
\text { assistants }\end{array}$ & $\begin{array}{l}\text { The assistant translates } \\
\text { each instructor's } \\
\text { instructions to the } \\
\text { students }\end{array}$ & $\begin{array}{l}\text { Students need more times to } \\
\text { understand the parts of } \\
\text { computers. However, } \\
\text { generally they can follow } \\
\text { the learning process well, } \\
\text { assisted by assistants. }\end{array}$ \\
\hline & Blind & - & - & - \\
\hline & $\begin{array}{l}\text { Physical } \\
\text { Disabled }\end{array}$ & $\begin{array}{l}\text { Instructors give instructions } \\
\text { in stages with standard } \\
\text { sentences and language to be } \\
\text { easily understood by students }\end{array}$ & $\begin{array}{l}\text { Assistants help the } \\
\text { students in removing } \\
\text { and installing the } \\
\text { materials }\end{array}$ & $\begin{array}{l}\text { Students can follow the } \\
\text { learning process and the } \\
\text { involvement of assistants } \\
\text { is quite minimal }\end{array}$ \\
\hline & $\begin{array}{l}\text { Mentally } \\
\text { disabled }\end{array}$ & - & - & - \\
\hline \multirow[t]{4}{*}{ Music } & Deaf & - & - & - \\
\hline & Blind & $\begin{array}{l}\text { The instructor } \\
\text { gives instructions in stages } \\
\text { with standard sentences } \\
\text { accompanied by physical } \\
\text { touch. The instructor } \\
\text { introduces equipment with } \\
\text { physical contact such as } \\
\text { holding, stroking or patting }\end{array}$ & $\begin{array}{l}\text { The assistants are } \\
\text { involved in helping the } \\
\text { students physically to } \\
\text { know the music } \\
\text { equipment. The ratio of } \\
\text { assistants and students } \\
\text { is } 1: 2 \text {, or } 1 \text { assistant } \\
\text { helps } 2 \text { students }\end{array}$ & $\begin{array}{l}\text { Students need extra } \\
\text { assistance to be able to } \\
\text { understand the instructions. } \\
\text { The involvement of } \\
\text { assistants to give physical } \\
\text { touch is quite high }\end{array}$ \\
\hline & $\begin{array}{l}\text { Physical } \\
\text { Disabled }\end{array}$ & $\begin{array}{l}\text { The structure gives the } \\
\text { instructions in stages with } \\
\text { standard sentences and } \\
\text { language to be easily } \\
\text { understood by students }\end{array}$ & $\begin{array}{l}\text { Assistants help the } \\
\text { students to singing well }\end{array}$ & $\begin{array}{l}\text { Students can follow the } \\
\text { learning process and the } \\
\text { involvement of assistants } \\
\text { is quite minimal }\end{array}$ \\
\hline & $\begin{array}{l}\text { Mentally } \\
\text { disabled }\end{array}$ & $\begin{array}{l}\text { Instructors give instructions } \\
\text { in stages with standard } \\
\text { sentences and language to } \\
\text { be easily understood } \\
\text { by students. Assistants are } \\
\text { accompanied by the the } \\
\text { parents of students to carry } \\
\text { out the instructor's } \\
\text { instruction }\end{array}$ & $\begin{array}{l}\text { The assistant is } \\
\text { involved in helping the } \\
\text { students to focus on } \\
\text { singing }\end{array}$ & $\begin{array}{l}\text { Students must be } \\
\text { accompanied by assistant, } \\
\text { even parents, in order to } \\
\text { follow instructions since } \\
\text { most of the them tend not to } \\
\text { focus in class }\end{array}$ \\
\hline
\end{tabular}




\section{a. Instructor}

In teaching cooking, crafts, computers, and music, the instructors provide instruction in stages with standard sentences and languange to be easily understood by students and assistants. The role of the assistant as an intepreter is very influential especially for the deaf groups. In the blind group class, the instructors provide students with verbal and physical touches such as; holding, stroking and tapping. For physical disabled students, the instructors provide students through the examination without neglecting the physical shortcomings of the students. In the mentally disabled class, instructors are required to understand the problem of each student. This type of students must be accompanied by parents since they tend to be unfocus in class and have a low level of understanding.

Instructors face different difficulties in providing learning processes for each student, each class. For example, the difficulties in explaining the names of tools for the deaf class (Puspita, 2018), meanwhile, instructors are required to have physical contact with the students one by one to provide a minimum understanding of the learning process in class (Jurik, et al, 2014).

The instructor's knowledge and experience in providing information and facilitating the students is very influential in creating comfortable classes. Moreover, the cooperation of instructors and assistants helps students understand the material delivered by the instructor. The completeness of facilities and equipment in the classroom also really helps the instructor to provide understanding to students. Last but not least, in dealing with students who have physical limitations and different characters, patience is the main key.

\section{b. Assistant}

The instructors and students must be assisted by assistant, especially for deaf, blind, and mentally disabled groups. For the deaf group, the assistant helps students understand the commands by translating the instructions. In the blind group, the role of assistants is very instrumental in helping students understand the instructions by giving physical touches to the students. For this type of disability, the ratio of assistants and students is 1: 2, or 1 assistant helps 2 students. In the physical disabled class, assistants tend to be more helpful in technical problems such as getting the equipments or doing specific thing that they can not do due to their physical limitations. Whereas, in the mentally disabled group, the assistants need to make coordination with the parents in helping students to focus on the instructions and the given task.

In the learning process, assistants face various kinds of obstacles as well. For example, in the deaf-student class, the assistant must be able to use sign language to reexplain the instructor's explanation. Likewise, the instructor must understand and be able to convey what the student wants to the instructor. In the blind-student class, more assistants are needed than other classes to help students understand the learning material. Whereas, in the physical-student class, the needs of assistants are not as many as other types of dissabilities.

The success of assistance depends greatly on the ability of the assistant in translating material provided by the instructor. Likewise, the success of an assistant is also influenced by the ability of the assistant in facilitating students to be actively involved in the learning process. The number of assistants also influences the success of the learning process, especially for the blind and deaf classes which need more assistants. The comparison of the number of assistants and students depends on the type of class. The posible ratio in the deaf class is one assistant versus two students, while for blind students, it is better to have one assistant versus one student. In addition, the success of assistance depends on the availability of facilities and equipment (Wessel, et al. 2009).

\section{c. Students}

Students generally can follow the learning process led by the instructor if they are assisted by assistants. Physical disabled students tend more capable to understand the instructions and follow the learning steps. Meanwhile, the deaf groups are easier to understand the instructions if assisted by assistants through sign language. Then, teaching the blind group is more difficult than physical and deaf since they need repeated physical touches. Finally, mentally disabled students need to be accompanied by parents since only the parents who know them well. This type of students has a very rapid mood change and having parents in the class really help the instructors and assistant to communicate with the students.

Students' difficulties in following the learning process is influenced by their physical limitations, their motivations related to the ability they have, their intelligences in understanding the material, and their limited time of the learning process. Motivation greatly affects students to participate and be involved in the learning process until completion. Therefore, the success of the learning process will be better if the students have relevant background to the learning process (Larasatri \& Indriana, 2017). These experiences will form a motivation to gain new understanding related to the experience they have. Thus, the material obtained will support students to be able to be more motivated to work (Brady-Amoon \& Fuertes, 2011). 


\section{Conclusion}

The learning process of creative industries for people with disabilities runs quite effectively with marked output from each class. The effectiveness of learning is greatly influenced by the presence of instructors who are assisted by assistants in escorting students. The instructor's involvement is not limited to the ability to provide knowledge but emotional involvement in directing students.

Each class has different types of difficulties depends on the types of the disabilities. Deaf groups understand the instructions by taking attention on sign language. Blind groups need more assistance especially when they have to do something. The physical disabled students tend to be more normal since they have good understanding on the instructions, and in their class, the involvement of assistant is quite minimal. The learning process on the mentally disabled students is more difficult and challanging than any other types of disabilities.

\section{References}

Amalia, A.D. (2014). Evaluasi outcome bagi individu program rehabilitasi sosial disabilitas netra: Studi kasus empat alumni PSBN Wyata Guna Bandung. Jurnal Informasi, 19, 260-283.

Andayani \& Afandi, M (2016) Pembedayaan dan Pendampingan Komuniktas Penyandang Disabilitas dalam Mengakses pendidikan tinggi, Aplikasia; Jurnal Aplikasi Ilmu-ilmu Agama, 16(2), 153-166

Brady-Amoon, P., \& Fuertes, J. N. (2011). Self-efficacy, self-rated abilities, adjustment, and performance. Journal of Counseling and Development, 89, 431-438

Efendi, A.B \& Yunianto, R (2017), Implementasi Diversity Program bagi tenaga kerja penyandang disabilitas pada PT Wangta Agung kota Surabaya, Indonesia Journal of Disability Studies, 4(2), 96-103

Friend, M \& dan D. Bursuck, W.D, (2015), Menuju Pendidikan Inklusi, Yogyakarta: Pustaka Pelajar

Griffin T, \& Nechvoglod L. (2008). Vocational Education and Training and People With a Disability: A Review of the Research. National Centre for Vocational Education Research

Ilahi, M.T. ( 2016). Pendidikan Inklusif Konsep \& Aplikasi. Jogjakarta: Ar-Ruzz Media.

Jurik, V., Alexander, G. \& Tina, S. (2014). Predicting students cognitive learning activity and intrinsic learning motivation: How powerful are teacher statements, student profiles, and gender?.Learning and Individual Differences Journal, 32, 132-139.

Larasatri, F.H \& Indriana (2017), Perbedaan motivasi belajar pada penyandang dsiabitas netra di Barehsos disabilitas netra provinsi Jawa Tengah ditinjau dari riwayat disabilitas, tingkat disabilitas dan jenis kelamin, Jurnal Empati, 6(1), 158-163

Puspita (2018). Pengaruh Motivasi Belajar Dan Percaya Diri Terhadap Hasil Belajar Pendidikan Jasmani Olahraga Pada Siswa Tunarungu Sekolah Luar Biasa, SPORTIVE: Journal of Physical Education, Sport and Recreation. 1(2), 18-26

Sidiq, S, Sudarsono. H, Mumpuni, S \& Perdana, A.R.A (2018) Analysis of potential creative industry for people with disabilitiesin special region of (D.I) Yogyakarta, Mimbar, jurnal Sosial dan Pembangunan, 34(1), 102-111

Sulthon. (2013) Mengenal Pendidikan Multikultural bagi Anak Berkebutuhan Khusus dengan Model Inklusi dalam Pendidikan Islam. ADDIN. 7 (1). 202-203

Wessel, R. D., Jones, J. A., Westfall, C., \& Markle, L. (2009). Retention and graduation of students with disabilities: Facilitating student success. Journal of Postsecondary Education and Disability, 21, 116-125. 